Vol. 8 No. 2 Juli 2018

E-ISSN: 2502-3101 P-ISSN: 2302-528x

http: //ojs.unud.ac.id/index.php/jmhu

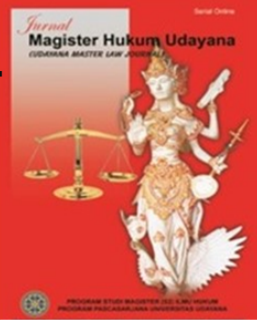

\title{
Problematika Penegakan Hukum Dalam Tindak Pidana Illegal Fishing di Wilayah Perairan ZEE Indonesia
}

\section{Dewa Ayu Maheswari Adiananda1, I Gede Eggy Bintang Pratama², Ida Ayu Brahmantari Manik Utama ${ }^{3}$}

\footnotetext{
1 Program Studi Magister Ilmu Hukum, Fakultas Hukum, Universitas Airlangga,

E-mail: dewa.ayu.nanda@gmail.com

2 Program Studi Magister Kenotariatan, Fakultas Hukum, Universitas Airlangga,

E-mail: eggybintang12@gmail.com

${ }^{3}$ Program Studi Magister Kenotariatan, Fakultas Hukum, Universitas Airlangga,

E-mail: dayugek29@gmail.com
}

\begin{tabular}{l} 
Info Artikel \\
\hline Masuk: 11 April 2019 \\
Diterima: 26 Juli 2019 \\
Terbit: 31 Juli 2019 \\
Keywords: \\
Law Enforcement; Illegal \\
Fishing: Economic Exclusive \\
Zone \\
Corresponding Author: \\
I Dewa Ayu Maheswari \\
Adiananda, E-mail:
\end{tabular}

\begin{abstract}
Illegal fishing lively going on in the area of the exclusive economic zone is still a threat to Indonesia. This situation is caused by the problem in the law enforcement process. In addressing this issue the Indonesian Supreme Court issued a Circular Letter to reaffirms the implementation of rules and prohibitions against it in UNCLOS 1982, even reap the difference of opinion between the Tribunal Judges that led to differences the verdict in the case. This research aims to analyze the problems and outlines the diversity among the judge ruling against illegal fishing with the promulgation of Circular Letter. This is empirical legal research which analysis documents as the technique. This research showed that in law enforcement against illegal fishing, the Supreme Court issued a circular letter Number 3 the Year 2015 concerning the ban on the overthrow of criminal confinement substitute fines for celebrating the existence of articles 73 on paragraph 3 of UNCLOS 1982. However, in its application in the field of implementation against the circular letter is difficult if the defendant cannot afford or do not want to pay criminal fines, which it is certainly going to lead to a recht vacuum. Against the foregoing, criminal confinement substitutes fines can be applied and does not conflict with Articles 73 paragraph (3) of the UNCLOS 1982 and Articles 102 of The Act of Fisheries, as mandated in the second such provision is there shouldn't be punishment imprisonment and beatings, while criminal confinement have a different understanding with imprisonment.

\begin{tabular}{l} 
Abstrak \\
\hline Penangkapan ikan yang dilakukan secara ilegal yang marak \\
terjadi di wilayah Zona Ekonomi Ekslusif masih menjadi \\
ancaman bagi Indonesia. Hal ini dikarenakan masih terdapat \\
problematika dalam proses penegakan hukumnya. Merespon \\
situasi ini, Mahkamah Agung mengeluarkan suatu Surat Edaran \\
Mahkamah Agung untuk mempertegas implementasi terhadap \\
aturan dan larangan dalam Konvensi Hukum Laut 1982, yang \\
justru malah menuai perbedaan pendapat di antara Majelis
\end{tabular}
\end{abstract}




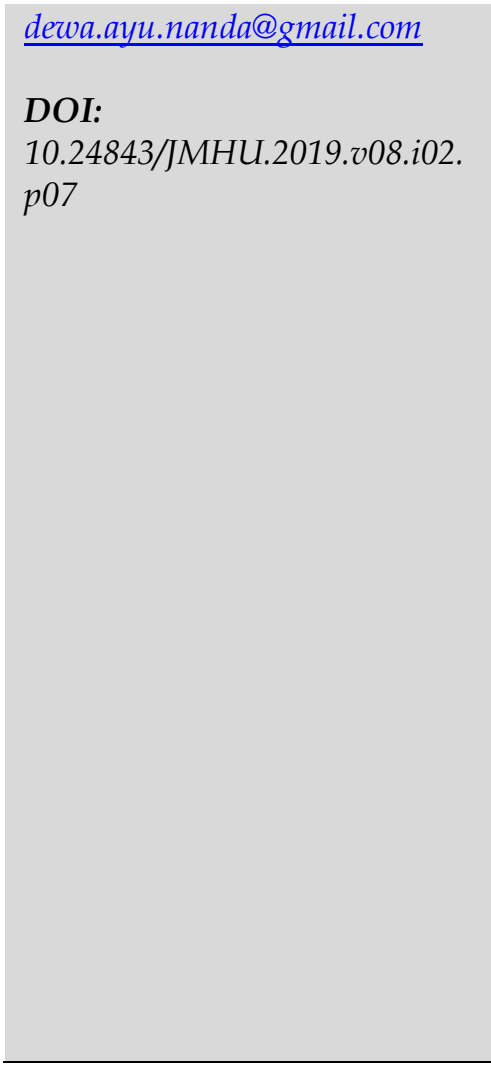

Hakim yang mengakibatkan terjadinya perbedaan putusan dalam perkara yang sama. Penelitian ini bertujuan untuk menguraikan dan menganalisis permasalahan mengenai keberagaman putusan di kalangan hakim agung terhadap kasus penangkapan ikan secara illegal dengan dikeluarkannya Surat Edaran tersebut. Dalam penelitian ini digunakan metode penelitian hukum empiris, dengan teknik studi dokumen dan analisis data. Hasil penelitian menunjukkan bahwa dalam penegakan hukum terhadap kasus penangkapan ikan secara illegal, terhadap Surat Edaran Mahkamah Agung Nomor 3 Tahun 2015 mengenai larangan penjatuhan pidana kurungan pengganti denda untuk mempertegas keberadaan Pasal 73 ayat (3) Konvensi Hukum Laut 1982. Namun dalam penerapannya di lapangan implementasi terhadap Surat Edaran tersebut sulit dilakukan bilamana terdakwa tidak mampu untuk membayar sejumlah pidana denda yang mana hal ini tentunya akan mengakibatkan kekosongan hukum. Terhadap hal tersebut, pidana kurungan sebagai pengganti denda tentu memungkinkan untuk diberlakukan selama tidak bertentangan dengan Pasal 73 ayat (3) Konvensi Hukum Laut 1982 dan Pasal 102 UU Perikanan, karena yang diamanatkan dalam kedua ketentuan tersebut ialah tidak boleh terdapat hukuman penjara dan hukuman badan, sedangkan pidana kurungan memiliki pengertian yang berbeda dengan pidana penjara.

\section{Pendahuluan}

Sejak abak ke-19, kebutuhan-kebutuhan dunia terkait keberadaan hukum laut terus berkembang hingga abad ke-20, yang menurut para pakar ialah sebagai puncak perkembangan tersebut, bahkan terus berkembang hingga saat ini. ${ }^{1} \mathrm{Hal}$ ini banyak disebabkan oleh keberadaan wilayah laut yang menjadi batas wilayah suatu negara dengan negara lainnya, yang kemudian mengakibatkan adanya pengaturan mengenai lebar wilayah laut kemudian menjadi penting. Sebagai salah satu contoh deklarasi mengenai hukum laut ialah Deklarasi Hukum Laut yang dilakukan di Lima. Deklarasi ini lebih mengedepankan bahwa orang-orang atau penduduk yang berdiam di wilayah darat boleh saja menggunakan, memanfaatkan dan bahkan mengolah kekayaan alam laut yang dekat dengan pantainya. ${ }^{2}$ Kemudian mulai muncul kegiatan-kegiatan atau konferensi-konferensi yang diakomodir oleh Perserikatan Bangsa-Bangsa (selanjutnya disingkat PBB) untuk membentuk rezim internasional yang mengatur mengenai definisi yang tepat dari batas pantai, masalah rezim laut lepas, landas kontinen, laut territorial (termasuk juga di dalamnya mengenai selat-selat internasional), jalur tambahan, perikanan, dan konservasi dan pelestarian lingkungan laut serta hak istimewa bagi negara pantai ${ }^{3}$ Kemudian oleh PBB hal-hal ini ditetapkan pada Konferensi PBB mengenai Hukum Laut Pertama di Jenewa tahun 1958. Ini telah menunjukkan bahwa, keinginan negara-negara atas kedaulatan di wilayah laut sudah berlangsung sejak lama, dan hal inilah yang kemudian diakomodir terus menerus oleh PBB sehingga kemudian

\footnotetext{
${ }^{1}$ Kusumaatmadja, M. (1986). Hukum Laut Internasional. Bandung: Bina Cipta, h. 2.

2 Aida, M. (2012). Penanggulangan Penangkapan Ikan Secara Tidak Sah (Illegal Fishing) Oleh Kapal Ikan Asing di ZEE Indonesia. Fiat Justitia Jurnal Ilmu Hukum, (5)2, h. 1-2.

${ }^{3}$ Ibid., h. 4-6.
} 
terbentuk kesepakatan terhadap suatu Konvensi Hukum Laut atau United Nations Convention on The Law of The Sea (yang selanjutnya disingkat dengan UNCLOS), mulai dari UNCLOS I (1958), UNCLOS II (1960), sampai UNCLOS III (tahun 1982). ${ }^{4}$

UNCLOS $1982^{5}$ yang telah diratifikasi Indonesia pada tanggal 31 Desember 1985 melalui pembentukan Undang-Undang Nomor 17 Tahun 1985 tentang Ratifikasi Indonesia Terhadap UNCLOS (selanjutnya disebut UU Ratifikasi UNCLOS) memberikan hak dan kewajiban yang lebih bagi Indonesia untuk memanfaatkan serta mengatur segala aspek mengenai kekayaan laut sampai pada wilayah perairan Zona Ekonomi Eksklusif (yang selanjutnya disingkat ZEE). ${ }^{6}$ Wilayah ZEE sesuai dengan Pasal 55 secara singkat menyatakan bahwa ZEE letaknya berdampingan dengan laut territorial, dan tunduk pada rezim hukum khusus dalam bab tersendiri pada UNCLOS 1982 dengan didasarkan pada hak serta yurisdiksi negara pantai. Mengenai hak negara lain, diatur dalam ketentuan lain namun masih tercakup dalam UNCLOS 1982. Lebar wilayah ZEE menurut Pasal 57 UNCLOS 1982 ialah tidak lebih dari 200 mil laut dengan dasar ukur dari garis pangkal.

Pada wilayah ZEE berlaku hak berdaulat (sovereign rights) bagi negara pantai, yang mana artinya negara pantai memiliki hak untuk melakukan kegiatan berupa eksplorasi, eksploitasi dan konservasi tidak hanya terbatas pada sumber daya alam atau kekayaan laut, melainkan juga meliputi penerbangan, pendirian pulau buatan (reklamasi), penggunaan riset-riset ilmiah serta penanaman kabel. ${ }^{7}$ Indonesia juga telah mengadopsi ketentuan UNCLOS dan mengatur wilayah ZEE Indonesia (yang selanjutnya disingkat ZEEI) dalam ketentuan tersendiri yakni Undang-Undang Nomor 5 Tahun 1983 tentang ZEEI (yang selanjutnya disebut UU ZEEI). Pembentukan UU ZEEI merupakan realisasi yuridis perluasan wilayah laut dalam upaya untuk pemanfaatan sumber daya laut dengan sebaik mungkin.

Kondisi geografis Indonesia terdiri atas 2/3 lautan dengan beragam sumber kekayaan alam di lautnya. ${ }^{8}$ Potensi laut Indonesia yang cukup tinggi inilah yang membuat banyak pihak termasuk negara asing tertarik dan/atau tergiur untuk memanfaatkan bahkan hingga mencurinya. Salah satu potensi terbesar ialah kekayaan ikannya. Kekayaan ikan yang begitu besar harus dapat dilindungi dari berbagai penangkapan ikan yang illegal (illegal fishing) yang dilakukan oleh perorangan ataupun korporasi baik dari warga negara Indonesia sendiri ataupun warga negara asing. 9 Menurut Kementerian Kelautan dan Perikanan (yang selanjutnya disingkat KKP), terdapat banyak pencurian ikan di wilayah laut Indonesia dan merugikan Indonesia sebesar 20 juta dollar AS setiap tahunnya. ${ }^{10}$ Keberadaan kapal-kapal asing tanpa izin yang terus

${ }^{4}$ Marhaeni, R.S. (2010). Hukum Perikanan Nasional dan Internasional. Jakarta: Gramedia Pustaka Utama. h. 93.

${ }^{5}$ Yang baru mulai efektif berlaku pada tahun 1994 setelah Guyana menjadi negara ke-60 (enam puluh) sebagai negara penandatangan konvensi.

${ }_{6}$ Marhaeni, R.S., Op.cit., h. 95-96.

7 Lihat Pasal 56 UNCLOS.

${ }^{8}$ Efritadewi, A. dan Jefrizal, W. (2017). Penenggelaman Kapal Illegal Fishing di Wilayah Indonesia Dalam Perspektif Hukum Internasional. Jurnal Selat. (4)2, h. 2.

${ }^{9}$ Endri. (2015). Penanggulangan Kejahatan Illegal Fishing di Kepulauan Riau. Jurnal Ilmu Hukum UNRI. (5)2, h. 2.

${ }^{10}$ Isnurhadi, M.R. (2017). Sekuritisasi Illegal, Unreported, Unregulated Fishing (IUUF) di Perairan Indonesia di Era Pemerintahan Joko Widodo. Jurnal Hubungan Internasional UNAIR. (X)2, h. 14 . 
mencuri dan mengeksploitasi perairan Indonesia juga memperparah keadaan tersebut. ${ }^{11}$ Bukan menjadi rahasia lagi bahwa masalah klasik, bahkan sudah menjadi hal yang lumrah dihadapi oleh negara dengan banyak pantai seperti Indonesia adalah illegal fishing. ${ }^{12}$ Dalam melakukan upaya penegakan hukum terhadap tindak pidana illegal fishing, Indonesia telah mengamanatkan ketentuan-ketentuan dalam UNCLOS 1982 ke dalam UU Perikanan, demikian pula Mahkamah Agung (yang selanjutnya disingkat MA) telah mengeluarkan suatu Surat Edaran MA terkait pidana yang dapat diberlakukan kepada pelaku illegal fishing. SEMA ini tidak memperbolehkan terdakwa untuk dijatuhi kurungan pengganti denda. Kendati demikian, justru keberadaan SEMA ini menuai problematika tersendiri di antara para hakim majelis MA dalam memutus perkara illegal fishing.

\section{Metode Penelitian}

Tulisan ini menggunakan metode penelitian empiris yang mana pada penelitian ini hukum dikonsepkan sebagai suatu gejala empiris yang dapat diamati dalam kehidupan nyata. ${ }^{13}$ Dalam penelitian ini digunakan pendekatan berupa pendekatan perundangundangan (the statute approach), melalui telaah terhadap peraturan perundang-undangan serta regulasi-regulasi hukum yang ada kaitannya dengan isu hukum yang sedang dibahas, ${ }^{14}$ dan dalam hal ini berbagai aturan hukum tersebut yang menjadi fokus sekaligus titik sentral dari penelitian. Di samping itu, pendekatan analisis konsep hukum (conceptual approach) juga merupakan pendekatan lain yang digunakan dalam penelitian ini. Penelitian ini diawali dengan mendeskripsikan fakta hukum, kemudian mencari pemecahan terhadap suatu perkara hukum dengan tujuan untuk menyelesaikan perkara hukum tersebut. ${ }^{15}$ Dalam penelitian ini digunakan bahan hukum primer serta bahan hukum sekunder. Bahan hukum primer dalam penelitian ini yakni UNCLOS 1982, UU Perikanan, UU ZEEI dan SEMA Nomor 3 Tahun 2015. Kemudian untuk bahan hukum sekunder berupa buku-buku, jurnal-jurnal dan literatur lainnya yang terkait dengan pembahasan illegal fishing di wilayah ZEE Indonesia. Teknik pengumpulan yang digunakan ialah studi dokumen yang dilakukan dengan menelaah bahan-bahan hukum yang relevan dengan pembahasan penelitian dan juga melalui metode bola salju.

\section{Hasil Penelitian Dan Pembahasan}

\subsection{Kedaulatan Negara Terhadap Wilayah Zona Ekonomi Eksklusif}

\subsubsection{Perihal ZEE}

ZEE merupakan salah satu pranata hukum laut yang masih relatif baru ditetapkan melalui UNCLOS 1982. ZEE dapat dipandang puncak dari adanya klaim sepihak oleh negara-negara ataupun masyarakat internasional terhadap sumber daya perikanan laut

11 Ibid., h. 14-15.

12 Tarigan, M.I. (2018). Implementation of Countermeasures Effort of Illegal Fishing in Indonesia (Case Study on Sinking the FV Vessel). Jurnal UNNES. (3)1, h. 137.

13 Fajar ND, M. dan Achmad, Y. (2010). Dualisme Penelitian Hukum Normatif \& Empiris. Yogyakarta: Pustaka Pelajar, h.34.

14 Marzuki, P.M. (2005). Penelitian Hukum. Jakarta: Prenada Media, h. 93.

${ }^{15}$ Amirudin, Z.A. (2010). Pengantar Metode Penelitian Hukum. Jakarta: Rajawali Pers, h. 118. 
lepas yang mana berbatasan dengan laut teritorialnya masing-masing, yang mana klaim tersebut secara terus menerus berlangsung secara berkesinambungan dan/atau berkelanjutan. ZEE sendiri dapat diartikan sebagai:

"bagian perairan (laut) yang terletak di luar dari dan berbatasan dengan laut territorial selebar 200 mil laut diukur dari garis pangkal dari mana lebar laut territorial diukur."16

Pengertian ZEE dalam UNCLOS 1982 tercantum dalam Pasal 55, dan beberapa prinsip dasar dalam ZEE yang termaktub dalam pasal tersebut di antaranya: ${ }^{17}$

1. letak ZEE secara geografis berada di luar wilayah laut territorial;

2. kendatipun berada di luar wilayah laut territorial, yang mana letaknya berdampingan dengan laut territorial;

3. lebar 200 mil dilakukan pengukurannya dari garis pangkal;

4. lebar ZEE sesungguhnya hanyalah 188 mil laut; 18

5. ZEE bukanlah bagian dari wilayah negara pantai. Oleh sebab itu pada ZEE, negara pantai hanya memiliki hak-hak berdaulat dan yurisdiksi yang sifatnya eksklusif.

\subsubsection{Kedaulatan Negara Terhadap Wilayah ZEE}

ZEE dalam UNCLOS 1982 diatur dalam pada bagian ke-5, dimulai dari Pasal 55 sampai dengan Pasal 75. Seperti yang tercantum pada Pasal 55 UNCLOS 1982 bahwa ZEE ialah suatu daerah yang letaknya berada diluar seraya berdampingan dengan laut territorial dan tunduk pada rezim khusus. Dan seperti telah dijelaskan sebelumnya, bahwa dalam kaitannya dengan ZEE, negara pantai memiliki hak-hak berdaulat. Adapun hak-hak berdaulat dari negara pantai pada ZEE ialah: ${ }^{19}$

1. Negara pantai memiliki hak berdaulat untuk melakukan kegiatan eksplorasi, eksploitasi, konservasi serta melakukan perawatan terhadap sumber daya alam baik hayati maupun non-hayati mulai dari dasar laut serta tanah yang terletak di bawahnya;

2. Negara pantai memiliki hak berdaulat terhadap kegiatan eksplorasi dan eksploitasi seperti produksi energi dari air, arus serta angin.

Sementara itu, Pasal 56 ayat (1) huruf b UNCLOS juga memberikan hak kepada negara pantai terhadap wilayah ZEE, berkenaan dengan pemanfaatan pulau buatan dalam kaitannya untuk kegiatan riset ilmiah kelautan serta perlindungan terhadap laut. Namun dalam melaksanakan kewajibannya (sesuai aturan dalam UNCLOS 1982), hakhak dan kewajiban negara lain tetap harus diperhatikan oleh negara pantai. ${ }^{20}$

16 Parthiana, I.P. (2014). Hukum Laut Internasional dan Hukum Laut Indonesia. Bandung: Yrama Widya, h. 144.

17 Ibid., h. 144-145.

${ }^{18}$ hal ini disebabkan laut selebar 12 mil dari garis pangkal sudah merupakan laut territorial yang merupakan bagian wilayah negara pantai dan tunduk pada kedaulatan negara pantai itu sendiri.

${ }^{19}$ Anwar, C. (1988). Horizon Baru Hukum Laut Internasional. Jakarta: Rhineka Cipta, h. 45.

${ }^{20}$ Muhamad, S.V. (2012). Ilegal Fishing di Perairan Indonesia, Permasalahan dan Upaya Penanganannya Secara Bilateral di Kawasan. Jurnal Politica. (3)1, h. 67. 
Negara pantai mempunyai hak dan kewajiban terhadap penegakan hukum serta penerapan terhadap peraturan perundang-undangannya pada wilayah ZEE yakni: ${ }^{21}$

1. Melakukan tindakan-tindakan terhadap kapal dan awak kapal asing seperti melakukan inspeksi, melakukan penahanan dan mengajukan kasus ke pengadilan;

2. Membebaskan kapal dan awak kapal asing setelah membayar uang jaminan;

3. Melakukan penahanan terhadap kapal dan awak kapal asing dan memberitahukan sejumlah denda kepada negara bendera kapal atau negara yang bersangkutan;

4. Apabila tidak terdapat perjanjian internasional sebelumnya, negara pantai tidak dibenarkan melakukan hukuman penjara atas pelanggaran hukum terhadap illegal fishing yang terjadi di ZEE.

\subsection{Problematika Hukum Nasional Indonesia Terhadap Illegal Fishing Dengan Dikeluarkannya SEMA Nomor 3 Tahun 2015}

\subsubsection{Regulasi Nasional dan Internasional Terkait Illegal Fishing}

Penegakan hukum dalam penanggulangan illegal fishing telah diundangkan melalui Undang-Undang Nomor 45 Tahun 2009 tentang Perubahan Atas Undang-Undang Nomor 31 Tahun 2004 tentang Perikanan (yang selanjutnya disingkat UU Perikanan). Penegakan hukum terhadap illegal fishing di wilayah ZEEI diatur dalam Pasal 97 ayat (2), Pasal 102, dan Pasal 104 ayat (1). Pasal-pasal ini merupakan pengadopsian dari ketentuan-ketentuan mengenai ZEE yang terdapat pada UNCLOS 1982. Pasal 97 ayat (2) UU Perikanan ini menyatakan bahwa kapal penangkap ikan berbendera asing dapat dipidana denda paling banyak $\mathrm{Rp}$ 1.000.000.000,00 (satu miliar rupiah) apabila membawa alat penangkap ikan lain selain yang diatur dalam undang-undang ini. Karena undang-undang ini hanya memperbolehkan satu jenis alat penangkapan ikan tertentu pada bagian tertentu di wilayah ZEEI.22

Kemudian ketentuan Pasal 102 UU Perikanan mengatur ketidakberlakuan pidana penjara terhadap tindakan pelanggaran pada bidang perikanan yang terjadi dibawah pengelolaan Indonesia. Ketentuan ini merupakan pengadopsian sekaligus implementasi terhadap Pasal 73 ayat (3) UNCLOS 1982 yang mengatur bahwa "Coastal State penalties for violations of fisheries laws and regulations in the exclusive economic zone may not include imprisonment, in the absence of agreements to the contrary by the States concerned, or any other form of corporal punishment."

Keberadaannya dipertegas melalui dikeluarkannya Surat Edaran Mahkamah Agung Nomor 3 Tahun 2015 mengenai Pemberlakuan Rumusan Hasil Rapat Pleno Kamar Mahkamah Agung Tahun 2015 sebagai Pedoman Pelaksanaan Tugas Bagi Pengadilan (selanjutnya disingkat SEMA 3/2015), yang pada huruf A angka 3 menyatakan "mengenai perkara illegal fishing di wilayah ZEEI, terhadap terdakwa hanya dapat dikenai pidana denda tanpa dijatuhi kurungan pengganti denda." Dikeluarkannya SEMA ini tentunya untuk dapat dijadikan sebagai acuan dalam setiap putusan pengadilan yang berkaitan dengan tindak pidana illegal fishing di wilayah ZEEI.

Untuk mempertegas aturan-aturan sebelumnya, kemudian Pasal 104 ayat (1) UU Perikanan mengatur bahwa terkait permohonan terhadap pembebasan kapal beserta

${ }^{21}$ Setyadi, I.Y.W. (2014). Upaya Negara Indonesia Dalam Menangani Masalah Ilegal Fishing Di Zona Ekonomi Eksklusif Indonesia. Jurnal UAJY, h. 5-6.

${ }^{22}$ Fernandes, I. (2017). Tinjauan Yuridis Illegal Fishing di Indonesia Berdasarkan UndangUndang Perikanan. Jurnal Hukum Respublica. (1)17, h. 205-206. 
awak kapal asing yang tertangkap, hanya dapat dilakukan jika negara bendera kapal telah melakukan upaya berupa penyerahan dengan uang jaminan yang dianggap layak, dan untuk itu penetapannya merupakan kewenangan peradilan perikanan.

Ketentuan dari Pasal ini juga merupakan suatu pengadopsian dari Pasal 73 ayat (2) UNCLOS 1982, yang mana menyatakan bahwa "Arrested vessels and their crews shall be promptly released upon the posting of reasonable bond or other security."

Kendati demikian, belum dapat terwujud pelaksanaan yang baik terhadap keberadaan dari Pasal 104 ayat (1) UU Perikanan ini. Padahal ketentuan ini dapat dimanfaatkan sebagai sumber pendapatan negara bukan pajak apabila dilihat dari banyaknya tindak pidana illegal fishing yang terjadi di wilayah ZEE. ${ }^{23}$ Hal ini dapat dikarenakan oleh beberapa faktor diantaranya, belum terdapat ketentuan lebih lanjut mengenai standar operasional prosedur mengenai pelaksanaan uang jaminan, tidak adanya regulasi dalam dunia internasional mengenai tanggungjawab negara bendera kapal, serta tidak terdapat niat baik dari pemilik kapal atau perusahaan pemilik kapal asing untuk membayarkan uang jaminan tersebut. ${ }^{24}$

\subsubsection{Problematika Putusan Mahkamah Agung Terhadap Kasus Illegal Fishing Dengan Dikeluarkannya SEMA Nomor 3 Tahun 2015}

Melalui website resmi Mahkamah Agung terdapat 192 putusan terkait illegal fishing, dan 101 perkara dari jumlah putusan tersebut merupakan kasus illegal fishing yang terjadi di wilayah ZEEI. Dapat dilihat pada tabel berikut:

\section{Tabel 1. Kasus illegal fishing yang terjadi di wilayah ZEEI}

\begin{tabular}{lcc}
\hline \multicolumn{1}{c}{ Pengadilan } & \multicolumn{2}{c}{ Putusan } \\
\cline { 2 - 3 } & Denda & Kurungan Pengganti Denda \\
\hline $\begin{array}{l}\text { Pengadilan Perikanan } \\
\text { Medan }\end{array}$ & 2 & - \\
\hline $\begin{array}{l}\text { Pengadilan Perikanan } \\
\text { Pontianak }\end{array}$ & 3 & - \\
\hline $\begin{array}{l}\text { Pengadilan Perikanan } \\
\text { Tanjung Pinang }\end{array}$ & 16 & 4 \\
\hline $\begin{array}{l}\text { Pengadilan Perikanan } \\
\text { Ranai }\end{array}$ & - & 27 \\
\hline $\begin{array}{l}\text { Pengadilan Negeri Aceh } \\
\text { Pengadilan Negeri } \\
\text { Bengkalis }\end{array}$ & - & 1 \\
\hline $\begin{array}{l}\text { Pengadilan Negeri } \\
\text { Langsa }\end{array}$ & - & 2 \\
\hline
\end{tabular}

${ }^{23}$ Risnain, M. (2017). Rekonsepsi Model Pencegahan dan Pemberantasan Illegal Fishing di Indonesia. Jurnal Ilmu Hukum Padjadjaran. 4(2): 379-398, h. 384.

${ }^{24}$ Dalam kasus kapal Indonesia yang ditangkap di Australia, ketentuan UNCLOS ini sudah di aplikasikan. Pada kasus tersebut, KM Perintis Jaya 19 (kapal berbendera Indonesia) ditangkap oleh otoritas Australia atas pelanggaran yang dilakukan di ZEE Australia. Kemudian perusahaan pemilik KM Perintis Jaya 19 memberikan uang jaminan kepada pemerintah Australia untuk membebaskan kapal dan awak kapal tersebut. (lihat Kusumaatmadja, M. (1990). Beberapa Masalah Pokok Sekitar Pengumuman Tentang Zona Ekonomi Eksklusif Indonesia. Majalah Hukum dan Pembangunan. (X)4, h. 389-390) 


\begin{tabular}{lcc}
\hline $\begin{array}{l}\text { Pengadilan Negeri } \\
\text { Sambas }\end{array}$ & - & 1 \\
\hline $\begin{array}{l}\text { Pengadilan Negeri } \\
\text { Tarakan }\end{array}$ & 1 & 1 \\
\hline $\begin{array}{l}\text { Pengadilan Negeri } \\
\text { Ternate }\end{array}$ & - & 1 \\
\hline $\begin{array}{l}\text { Pengadilan Tinggi } \\
\text { Pekanbaru }\end{array}$ & 3 & 12 \\
\hline $\begin{array}{l}\text { Pengadilan Tinggi } \\
\text { Kalimantan Barat }\end{array}$ & - & 2 \\
\hline $\begin{array}{l}\text { Pengadilan Tinggi } \\
\text { Kalimantan Timur }\end{array}$ & - & 2 \\
\hline $\begin{array}{l}\text { Pengadilan Tinggi } \\
\text { Jayapura }\end{array}$ & 1 & 2 \\
\hline Mahkamah Agung & 12 & 7 \\
\hline Total & 38 & 63 \\
\hline
\end{tabular}

Sumber: Direktorat Penanganan Pelanggaran PPNS Perikanan 2017

Yang menarik dari tabel putusan tersebut adalah terdapat perbedaan putusan dan/atau hukuman bagi para pelaku illegal fishing yang terjadi di wilayah ZEE. Dalam beberapa putusan, ada yang menjatuhkan pidana denda dan terdapat pula yang menjatuhkan pidana kurungan pengganti denda. Bahkan dalam di antara Majelis Hakim Agung yang memutus pun kerap kali terdapat perbedaan pandangan mengenai penjatuhan pidana terhadap kasus illegal fishing ini. Di satu sisi terdapat putusan yang memuat putusan terkait denda tanpa pidana kurungan pengganti denda, sebagaimana diamanatkan dalam Pasal 73 ayat (3) UNCLOS 1982, Pasal 102 UU Perikanan dan SEMA 3/2015 yang tidak memperbolehkan adanya penjatuhan pidana penjara dan hukuman badan lainnya kepada terdakwa apabila tidak terdapat perjanjian sebelumnya.

Di sisi lain, terdapat beberapa putusan yang memuat putusan dengan hukuman pidana kurungan pengganti denda. Dalam putusan-putusan ini, Majelis Hakim berdalih bahwa yang dilarang oleh Pasal 73 ayat (3) UNCLOS dan Pasal 102 UU Perikanan ialah penjatuhan pidana penjara dan hukuman badan, sedangkan pidana kurungan pengganti denda tidak diatur lebih lanjut, dan bagi hakim majelis merupakan salah satu upaya bilamana terdakwa tidak dapat membayar dan/ atau tidak berkeinginan untuk melakukan pembayaran terhadap putusan berupa denda yang dijatuhkan

Untuk lebih jelasnya, dalam penelitian ini akan dicantumkan perbandingan terhadap perbedaan pandangan dan/atau putusan Majelis Hakim, dimulai dari Putusan MA Nomor 99 K dengan Majelis Hakim yang terdiri atas Timur P. Manurung, Andi Samsan Nganro dan Eddy Army yang dalam putusannya menyatakan bahwa25 "Majelis hakim mengikuti aturan sebagaimana diatur dalam Pasal 73 ayat (3) UNCLOS 1982 dan tidak terdapat perjanjian antara Indonesia dan Vietnam, sebagaimana dimaksud Pasal 102 UU Perikanan."

Majelis Hakim ini menjatuhkan putusan pidana denda dalam kasus illegal fishing dengan terdakwa Mr. Duong van Tien. Kemudian contoh putusan pidana denda lainnya ialah Putusan MA Nomor 1355 K dengan Majelis Hakim yang terdiri atas Surya Jaya, Artidjo

${ }^{25}$ Putusan MA No_99K/pid.sus/2014 Tahun 2014, Mr Duong van Tien. 
Alkostar dan Sri Murwahyuni dengan terdakwa Dao van Tuan. ${ }^{26}$ Dalam putusannya menyatakan bahwa "Majelis hakim mengikuti aturan sebagaimana diatur dalam Pasal 73 ayat (3) UNCLOS 1982 dan Pasal 102 UUPerikanan karena merupakan lex specialis, untuk itu pidana berupa denda yang diputus tidak dapat dibebani kembali dengan pidana berupa kurungan dengan berbagai bentuk lain." 27

Sedangkan sebagai contoh Putusan MA yang memberi sanksi berupa pidana kurungan sebagai pengganti pidana berupa denda, diantaranya yakni Putusan MA Nomor $608 \mathrm{~K}$ dengan Majelis Hakim yang terdiri atas Artidjo Alkostar, Surya Jaya, dan Sri Murwahyuni dengan terdakwa Mr. Tra van Se. ${ }^{28}$ Dalam putusannya menyatakan:

“Majelis hakim berpendapat bahwa Pasal 73 ayat (3) UNCLOS 1982 terkait pelarangan pemberian pidana berupa penjara atau hukuman badan sebagai pidana pokok tertuang dalam Pasal 10 huruf (a) KUHAP, di lain hal penjara atau sanksi badan sebagai pengganti denda bukan merupakan pidana pokok sehingga terkesan sebagai "upaya" sehingga terdakwa melakukan pembayaran berupa denda. “

Dan satu contoh lainnya ialah Putusan MA Nomor $495 \mathrm{~K}$ dengan Majeslis Hakim yang terdiri atas Surya Jaya, Suhadi dan Margono, dengan terdakwa Jusnadi bin Bacconi, ${ }^{29}$ yang secara singkat dalam putusannya menyatakan bahwa ketentuan dalam Pasal 102 UUPerikanan dan Pasal 73 ayat (3) UNCLOS 1982 tidak melarang atau membatasi penerapan hukum selain pidana penjara pada ZEEI bagi pelaku asing, sehingga penjatuhan pidana kurungan pengganti denda dapat diterapkan sesuai dengan Pasal 30 ayat (2) KUHP yang menyatakan "jika pidana denda tidak dibayar, akan diganti dengan pidana kurungan."

Berbagai pertimbangan dari Majelis Hakim dalam memutus perkara illegal fishing di wilayah ZEEI membuktikan bahwa SEMA Nomor 3 Tahun 2015 yang melarang adanya pidana badan untuk menggantikan sejumlah uang terhadap terdakwa yang dapat dikenai pidana denda, tidak berjalan efektif dan belum dapat menjadi solusi atas adanya perbedaan pendapat di antara para Majelis Hakim MA tersebut. Dalam hal ini, yang perlu ditelaah lebih lanjut adalah mengenai tidak adanya instrumen hukum lain yang menyatakan mengenai apa yang bisa aparat penegak hukum lakukan bila pidana denda tidak dibayar atau mengenai hal ini dapat dikatakan telah terjadi suatu kekosongan hukum.

Dengan demikian, sebetulnya kurungan badan untuk menggantikan sejumlah uang sanksi memungkinkan untuk dilaksanakan dan sesungguhnya tidak pula melanggar ketentuan Pasal 73 ayat (3) UNCLOS dan Pasal 102 UU Perikanan. Hal ini didasarkan pada penafsiran kata "imprisonment" dalam pasal tersebut yang dapat diartikan sebagai

26 Putusan MA No_1355K/pid.sus/2014 Tahun 2015, Dao van Tuan.

${ }^{27}$ Namun dalam putusan tersebut terdapat perbedaan pandangan oleh Hakim Surya Jaya yang pada intinya berpendapat bahwa "...akan menimbulkan masalah jika terpidana asing tidak membayar denda, maka pihak imigrasi Indonesia tidak akan membiarkan terpidana asing untuk keluar dari wilayah Indonesia sebelum menyelesaikan kewajiban hukumnya yakni membayar denda, jika hal ini tidak terpenuhi maka imigrasi berwenang berhak melakukan pencekalan. Sebagai akibat dari pencekalan akan timbul masalah baru yaitu pembiayaan terhadap terpidana asing yang masih berada di penampungan aparat penegak hukum wilayah Indonesia tersebut. Di sisi lain, dalam UNCLOS tidak ada larangan bagi aparat penegak hukum untuk memutus penggantian sanksi kurungan dengan denda.

28 Putusan Mahkamah Agung Nomor 608 K/Pid.Sus/2013 tahun 2015, Mr. Tra van SE.

${ }^{29}$ Putusan Mahkamah Agung Nomor 495 k/Pid.Sus/ 2015 tahun 2016, Jusnadi bin Bacconi. 
"pemenjaraan" dan "corporal punishment" yang dapat diartikan sebagai hukuman badan. ${ }^{30}$ Pasal-pasal dalam UNCLOS 1982 beserta annex-annexnya tidak menjelaskan sejauh mana cakupan kata imprisonment dan corporal punishment tersebut. Sebagaimana konsep imprisonment dalam Pasal 9 ayat (1) huruf a angka 1 KUHP Belanda, Pasal 38 dan Pasal 39 KUHP Jerman, serta Pasal 13 angka 1 KUHP Perancis yang mengartikannya sebagai pemenjaraan dan/atau hukuman penjara. Sedangkan mengenai pidana badan tidak diadopsi oleh dalam sistem hukum pidana Indonesia. Pidana badan sebagai contoh diterapkan dalam sistem hukum islam pada jaman kerajaan, misalnya dalam perkara pembunuhan dapat dihukum pancung, dalam perkara pencurian dihukum potong tangan dan sebagainya. Jadi sekali lagi dapat dikatakan bahwa pidana kurungan pengganti denda tidaklah termasuk dalam kategori konsep pidana penjara (imprisonment) dan hukuman badan (corporal punishment). Dalam Pasal 73 ayat (3) UNCLOS 1982 serta Pasal 102 UU Perikanan pun tidak mencantumkan larangan penjatuhan pidana kurungan pengganti denda.

\section{Kesimpulan}

Penegakan hukum terhadap illegal fishing di wilayah ZEEI oleh Mahkamah Agung masih sulit dilakukan. Walaupun telah dipertegas melalui SEMA Nomor 3 Tahun 2015 untuk mempertegas keberadaan Pasal 73 ayat (3) UNCLOS yakni mengenai larangan pemberian sanksi badan sebagai pengganti sanksi denda. Dalam penerapannya di lapangan, implementasi terhadap SEMA tersebut sulit dilakukan apabila terdapat terdakwa yang tidak dapat serta tidak berkeinginan untuk melakukan pembayaran, bilamana hal ini tentunya akan mengakibatkan kekosongan hukum karena tidak terdapat konsekuensi yuridis lain yang dapat diterapkan kepada terdakwa. Terhadap hal tersebut, kurungan badan untuk menggantikan sanksi denda sangat memungkinkan untuk dilaksanakan dan sesungguhnya tidak pula melanggar ketentuan Pasal 73 ayat (3) UNCLOS serta Pasal 102 UU Perikanan, karena yang diamanatkan dalam kedua ketentuan tersebut ialah tidak boleh terdapat hukuman penjara dan hukuman badan, sedangkan pidana kurungan memiliki pengertian yang berbeda dengan pidana penjara. Selain itu, upaya pidana kurungan pengganti denda juga telah sesuai dengan ketentuan Pasal 30 ayat (2) KUHP.

\section{Daftar Pustaka}

\section{Buku}

Amirudin, Z.A. (2010). Pengantar Metode Penelitian Hukum. Jakarta: Rajawali Pers.

Anwar, C. (1988). Horizon Baru Hukum Laut Internasional. Jakarta: Rhineka Cipta.

Fajar ND, M. dan Achmad, Y. (2010). Dualisme Penelitian Hukum Normatif E Empiris. Yogyakarta: Pustaka Pelajar.

Kusumaatmadja, M. (1986). Hukum Laut Internasional. Bandung: Bina Cipta.

Marhaeni, R.S. (2010). Hukum Perikanan Nasional dan Internasional. Jakarta: Gramedia Pustaka Utama.

Marzuki, P.M. (2005). Penelitian Hukum. Jakarta: Prenada Media.

Parthiana, I.P. (2014). Hukum Laut Internasional dan Hukum Laut Indonesia. Bandung: Yrama Widya.

\footnotetext{
${ }^{30}$ Garner, B.A. (1999). Black's Law Dictionary. St. Paul USA: West Group, h. 761.
} 


\section{Kamus/Ensiklopedia}

Garner, B.A. (1999). Black's Law Dictionary. St. Paul USA: West Group.

Jurnal

Aida, M. (2012). Penanggulangan Penangkapan Ikan Secara Tidak Sah (Illegal Fishing) Oleh Kapal Ikan Asing di ZEE Indonesia. Fiat Justitia Jurnal Ilmu Hukum, (5)2: 1-21. https://doi.org/10.25041/fiatjustisia.v5no2.67

Efritadewi, A. dan Jefrizal, W. (2017). Penenggelaman Kapal Illegal Fishing di Wilayah Indonesia Dalam Perspektif Hukum Internasional. Jurnal Selat. (4)2: 260-272.

Endri. (2015). Penanggulangan Kejahatan Illegal Fishing di Kepulauan Riau. Jurnal Ilmu Hukum UNRI. (5)2: 1-26.

Fernandes, I. (2017). Tinjauan Yuridis Illegal Fishing di Indonesia Berdasarkan UndangUndang Perikanan. Jurnal Hukum Respublica, 17(1), 189-209.

Isnurhadi, M. R. (2018). Sekuritisasi Illegal, Unreported, Unregulated Fishing (IUUF) di Perairan Indonesia di Era Pemerintahan Joko Widodo. Jurnal Hubungan Internasional, 10(2), 13-27.

Kusumaatmadja, M. (1990). Beberapa Masalah Pokok Sekitar Pengumuman Tentang Zona Ekonomi Eksklusif Indonesia. Majalah Hukum dan Pembangunan. (X)4.

Muhamad, S.V. (2012). Ilegal Fishing di Perairan Indonesia, Permasalahan dan Upaya Penanganannya Secara Bilateral di Kawasan. Jurnal Politica. (3)1: 59-85. https://doi.org/10.22212/jp.v3i1.305

Risnain, M. (2017). Rekonsepsi Model Pencegahan dan Pemberantasan Illegal Fishing di Indonesia. Jurnal Ilmu Hukum Padjadjaran. 4(2): 379-398. https://doi.org/10.22304/pjih.v4n2.a9

Setyadi, I.Y.W. (2014). Upaya Negara Indonesia Dalam Menangani Masalah Ilegal Fishing Di Zona Ekonomi Eksklusif Indonesia. Jurnal UAJY. 1-15.

Tarigan, M.I. (2018). Implementation of Countermeasures Effort of Illegal Fishing in Indonesia (Case Study on Sinking the FV Vessel). Jurnal UNNES. (3)1: 131146.

\section{Instrumen Hukum Internasional}

United Nations Convention on The Law of The Sea 1982.

\section{Peraturan Perundangan}

Undang-Undang Nomor 17 Tahun 1985 tentang Ratifikasi Indonesia Terhadap UNCLOS Lembaran Negara Republik Indonesia Tahun 1985 Nomor 76.

Undang-Undang Nomor 5 Tahun 1983 tentang ZEEI Lembaran Negara Republik Indonesia Tahun 1983 Nomor 44.

Undang-Undang Nomor 31 Tahun 2004 tentang Perikanan Lembaran Negara Republik Indonesia Tahun 2004 Nomor 118, Tambahan Lembaran Negara Republik Indonesia Nomor 4433.

Undang-Undang Nomor 45 Tahun 2009 tentang Perubahan Atas Undang-Undang Nomor 31 Tahun 2004 tentang Perikanan

Lembaran Negara Republik Indonesia Tahun 2009 Nomor 154.

\section{Putusan Mahkamah Agung}

Putusan Mahkamah Agung Nomor 99 K/Pid.Sus/2014 tahun 2014, Mr Duong van Tien. Putusan Mahkamah Agung Nomor 1355 K/Pid.Sus/2014 tahun 2015, Dao van Tuan. Putusan Mahkamah Agung Nomor 608 K/Pid.Sus/2013 tahun 2015, Mr. Tra van SE. 
Putusan Mahkamah Agung Nomor 495 k/Pid.Sus/ 2015 tahun 2016, Jusnadi bin Bacconi.

\section{Surat Edaran Mahkamah Agung}

Surat Edaran Mahkamah Agung Nomor 03/BUA.6/HS/SP/XII/2015 tentang Pemberlakuan Rumusan Hasil Rapat Pleno Kamar Mahkamah Agung Tahun 2015 sebagai Pedoman Pelaksanaan Tugas Bagi Pengadilan. 